AL IBTIDA: JURNAL PENDIDIKAN GURU MI (2020) Vol 7 (2) : 148-165

DOI: http://dx.doi.org/10.24235/al.ibtida.snj.v7i2.4935

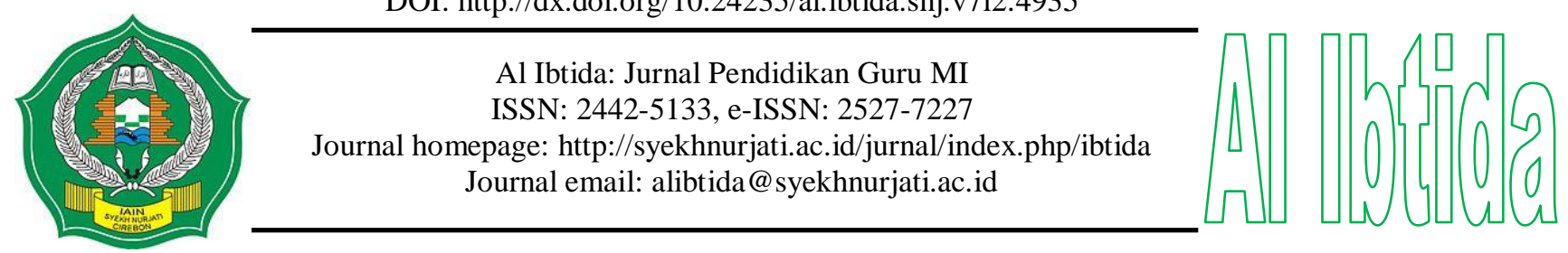

\title{
Utilization of Literature Based Math in Developing Didactic Designs for Students' Mathematical Understanding in the Decimal Concept
}

\author{
Wida Rachmiati* \\ *Department of Madrasah Ibtidaiyah Teacher Education, Faculty of Tarbiyah and Teacher Training, \\ Universitas Islam Negeri Sultan Maulana Hasanuddin Banten, Indonesia \\ Email: wida.rachmiati@uinbanten.ac.id \\ Helnanelis*** \\ **Department of Islamic Education, Faculty of Tarbiyah and Teacher Training, \\ Universitas Islam Negeri Sultan Maulana Hasanuddin Banten, Indonesia \\ Email: helnanelis@ uinbanten.ac.id
}

\author{
Juhji*** \\ ***Department of Madrasah Ibtidaiyah Teacher Education, Faculty of Tarbiyah and Teacher Training, \\ Universitas Islam Negeri Sultan Maulana Hasanuddin Banten, Indonesia \\ Email: juhji@uinbanten.ac.id
}

Received: August 07 ${ }^{\text {th }}, 2019$. Accepted: September 02 ${ }^{\text {nd }}, 2020$. Published: October $29^{\text {th }}, 2020$.

\begin{abstract}
This research is motivated by learning barriers and low understanding of the mathematical students of Madrasah Ibtidaiyah on the concept of decimal fraction. The purpose of this research is to determine the effective learning technique for decimal fraction by using storybook. This type of research uses didactical design research which includes the stages of prospective analysis, metapedia didactic analysis, and reprospective analysis. The draft of the design applied to twenty-eight students' sixth grade of Madrasah Ibtidaiyah Nurul Hidayah Kadupandak Serang City. Observation sheets, interviews, and test comprehension were used as a data collection instrument for implementation execution. Didactic design using literature based math was made through one revision and it consist of eight steps. The results showed that the implementation of didactical design using literature based math can help students build their mathematical understanding of the decimal concept. It can be seen from the reduced percentage of students' errors in solving comprehension test questions from $71.6 \%$ to $11.6 \%$. Therefore, for elementary teacher who has storybooks related to mathematical concepts are advised to try the eight learning steps developed in this study.
\end{abstract}

Keywords: literature-based math, didactic designs, students' mathematical understanding. 


\begin{abstract}
Abstrak
Penelitian ini dilatarbelakangi oleh hambatan belajar dan pemahaman matematis siswa Madrasah Ibtidaiyah yang masih rendah pada konsep pecahan desimal. Tujuan dari penelitian ini adalah untuk mengetahui efektifitas teknik pembelajaran pecahan desimal dengan menggunakan buku cerita. Jenis penelitian yang digunakan adalah penelitian desain didaktis yang meliputi tahapan analisis prospektif, analisis metapeda didaktik, dan analisis re-prospektif. Rancangan desain didaktis diterapkan pada 28 (dua puluh delapan) siswa kelas VI (enam) Madrasah Ibtidaiyah Nurul Hidayah Kadupandak Kota Serang. Lembar observasi, wawancara, dan tes pemahaman digunakan sebagai instrumen pengumpulan data dalam penelitian. Desain didaktis dengan menggunakan matematika berbasis literatur dibuat melalui satu kali revisi dan terdiri dari delapan langkah. Hasil penelitian menunjukkan bahwa penerapan desain didaktis dengan menggunakan matematika berbasis literatur dapat membantu siswa dalam membangun pemahaman matematika tentang konsep desimal. Hal tersebut terlihat dari berkurangnya persentase kesalahan siswa dalam menyelesaikan soal tes pemahaman dari 71,6\% menjadi 11,6\%. Oleh karena itu, bagi guru sekolah dasar yang memiliki buku cerita yang berkaitan dengan konsep matematika disarankan untuk mencoba delapan langkah pembelajaran yang dikembangkan dalam penelitian ini.
\end{abstract}

Kata kunci: matematika berbasis literatur, desain didaktis, pemahaman matematika siswa.

\title{
INTRODUCTION
}

The understanding of mathematical concepts is fundamental proficiency (Purpura et al., 2011; Cragg \& Gilmore, 2014; Wulandari, 2015; Yanti et al., 2019) which must be accomplished in the process of learning mathematics (Reys et al., 2014; Purwanti et al., 2016; Sari, 2017; Edriati et al., 2017). Understanding the concept of mathematics affects students' mathematical Learning outcomes (Stylianou, 2011; Planinic et al., 2012; Novitasari \& Leonard, 2017). Considering that mathematics is a lesson that requires centralizing thought to remember and re-identify the material learned (Hadi \& Kasum, 2015), it takes appropriate learning methods. According to Herman (2004), There are several consequences of mental processes that occur when learning is focused on understanding and purposing. The consequences are support memory, reduce the amount to remember, increase the transfer, and influence students's belief in mathematics.

Furthermore, Hendriana et al. (2017) stated that mathematical understanding is an important foundation for thinking and resolving mathematical and real-life issues. Besides, the ability of mathematical understanding is very important in the development of other mathematical capabilities, namely communication, problem-solving, reasoning, connection, representation, critical thinking, and creative thinking. Thus, the achievement of conceptual understanding can make students more enjoy in learning math. Because if the student reaches 
a strong understanding of the concept, then the student will reach the high level in conquering the math, so students will be inclined to enjoy the lessons.

In fact students's understanding in math is still a problem in learning activity (Mattuvarkuzhali, 2012; Planinic et al., 2012; Mensah et al., 2013; Hadi \& Kasum, 2015; Priyambodo, 2016; Pamungkas \& Afriansyah, 2017; Suraji et al., 2018) including in the fractional concept. The low understanding of mathematical concepts is due to the lack of the selection of learning models (Hadi \& Kasum, 2015), less optimal in using the media (Febriyanto et al., 2018), and concentrating on the practice of the problem (Luritawaty, 2018). Based on the observation and results of Class 6 interviews in three Madrasah Ibtidaiyah Serang City of Banten Province, it was found that another cause that resulted in the low understanding of students' mathematics on the concept of fractional is because students are faced with more complex symbols and lack of the concept of fractional use in daily life.

Fazio and Segler's (2011) in his research cited by Palpialy \& Nurlaelah (2015) suggests that in many countries, the average of student has never gained a good conceptual knowledge of fractions. For example on the national exam in the Americas, only 50\% of Grade 8 students are able to sort three shards correctly, from the smallest to largest value. While in countries such as China and Japan, the fraction is considered a difficult topic (Palpialy \& Nurlaelah, 2015). Thus, the fractional concept of mathematical learning is difficult for students to teach.

A preliminary study of Grade 6 students in three Madrasah Ibtidaiyah Serang City of Banten Province reported that students have not been able to solve problems in understanding the concept of a decimal fraction when they have learned the concepts. It has tested the previous class. Besides, some findings were obtained that: 1) students do not know the numbers on decimal fraction, it showed by some errors in performing arithmetic calculate operations and comparing decimal fractions; and 2) Students can operate fewer decimal fractions of 1 into the form of images, but they are experiencing difficulties for decimal fractions of more than 1 (mixed decimal fraction).

The results of interviews with teachers revealed that teachers have some obstacles in determining the right learning strategies for decimal fractional materials. According to them, teaching fractional concept using visual media is only done at the time of fractional introduction. However, in advanced fractional materials such as fractional value concepts, comparing fractions, counting, and fractional writing operations in other forms (decimal fractions), the learning process tends to emphasize on memorizing formulas. In fact, mathematical concepts, in particular, fractional concepts (including decimal fragments) must be presented in contextual form to facilitate students. Teachers don't sleep wanting to 
approach contextual learning, but they are limited by what kind of contextual learning ideas can be applied to decimal fractional material.

Hurst and Cordes's study (2018), reported that children had greater learning experience with fraction notation when they processed fractional notation. As for Desmet et al., (2010) reported that zero right after the decimal point is understood better and earlier than zero at the end of the fractional part of the number. Meanwhile, Lee et al., (2016) stated that fractions and decimals cannot be attributed to the specific units of education, language, and its measurement. For addressing the problem of students' learning difficulties in fractional decimal materials, Lain \& Wong (2017) in their research report suggested a theoretical framework. It is in line with Yildiz et al., (2011) that the development of instructional materials is able to increase student success in fractional decimal material. Thus, the development of didactic design is necessary in an effort to improve the success of students' learning on fractional decimal concepts.

This problem prompted researchers to develop a didactical design that is expected to help teachers and students to overcome learning constraints on fractional decimal numbers. The didactic design developed comes from Dick (2013); Suryadi \& Suratno (2016) by utilizing learning resources in the form of storybooks. Didactic design theory was developed from Warries (1990), Dick et al. (2001), and Chang (2006). Yun-fang's research (2012) reported in the paper that synchronizing pedagogical theory on didactic design is one of the important content. He also discussed "teaching design for learning" combined with learning characteristics in the engineering profession, basic principles in teaching, and presentation of the framework of both courses. Thus, it is considered important to develop didactic design because this book is a story related to the concept of mathematics for elementary school students quite a lot in the market.

Haury (2001) mentioned that the learning source of mathematics is presented as literature-based mathematics. In the early 1980, NCTM has already reviewed the benefits of using the storybook in Mathematics Learning (Lidinillah et al., 2015), the results of the study explaining that the storybook can: (1) present a rich context to understand mathematical ideas; (2) Show students how to view the world from a mathematical perspective; (3) Illustrate how mathematics has been used throughout history by humans to live their lives; (4) Illustrate interdisciplinary relationship to mathematics; and (5) awaken the imagination of the child and his curiosity.

According to Bafile (2001), combining mathematics and storytelling is a way for teachers to invite children into the world of mathematics, reading books that put together 
mathematical ideas into compelling stories that help dispel the myth that mathematics is dry, unimaginative, and inaccessible. Children's books can not only generate interest in mathematics but also provide the context that helps them to understand the meaning of an abstract concept. While Haury (2001) has classified various ways of using children's reading books in mathematics learning in elementary school, namely to: (1) present context and model for mathematical activities; (2) Introduce various manipulative media; (3) Inspire mathematical creative experiences; (4) Posing an interesting problem; (5) Preparing mathematical concepts and skills; (6) Develop and explain mathematical concepts or skills; (7) as well as to refer to mathematical concepts and skills. Based on these issues, the study aims to determine effective mathematical learning methods and techniques on the concept of decimal fractions by using storybooks as learning resources.

\section{METHODS}

This research is the Didactical Design Research (DDR) of Suryadi (2013), with the following stages of DDR: 1) A prospective analysis stage, i.e. the analysis of the Didactic and Pedagogical Situation (DPS) before learning, the synthesis of teacher thought outcomes based on the various possibilities predicted to occur in the learning event; 2) metapedadidactic analysis, i.e. analysis during the learning process which includes components of unity, flexibility, and coherence; 3) re-prospective analysis, which is the analysis associates to the results of DPS analyzers with the results of metapedadidactic analysis (Suryadi \& Suratno, 2016). The didactic design has been developed implemented in 28 grade 6 students at Madrasah Ibtidaiyah Nurul Hidayah Kadupandak Serang City of Banten Province in the 1st Semester of the academic year 2018/2019.

Interviews were conducted with teachers using interview sheets to obtain data about learning barriers before the didactic design was made. Observations are made to obtain data about what things are appropriate at the time of learning and are not by the didactic design draft. The essay test is used as a measuring instrument to know the students' understanding of mathematical concepts. The validity of the instrument is determined through the judgment of the mathematics education expert.

The flow of learning activities consists of three phases, including: (1) Preliminary study that is conducting the learning obstacle diagnosis test, identifying and analyzing the learning obstacle, setting the didactical design model to be developed based on learning obstacle; (2) The development of the didactic design, including: (a) a prospective analysis by making the design of the didactic (LIP) which includes the prediction of students ' response to be performed and its anticipator; (b) The analysis of metapedadidactic by implementing the 
design and learning processes that include components of unity, flexibility and coherence; and (c) re-prospective analysis by looking at the acceptability of the design didactically with students ' responses appearing during the implementation as a reference to the revision of the didactical design. Also in measuring the effectiveness of the design by providing a test of understanding and a questionnaire of reading interest to students; and (3) The final design model was didactic by making the conclusion of the design model Didactic.

\section{RESULTS AND DISCUSSION}

The results of the study through interviews with grade 6 teachers in three Madrasah Ibtidaiyah in Serang City, obtained information that students experienced obstacles in learning mathematics on the concept of a decimal fraction. Then observe the learning device used by the teacher on the fractional concept. The Learning Devices teachers use include: the LIP, the Book of packages, the media, and the Student Worksheets (SW). Analysis of the LIP focused on the concept: Change the fraction shape to another form and compare the fraction.

Findings obtained from the observation of the Learning Implementation Plan (LIP) are as follows: (1) Learning methods used to limit the conventional learning, i.e. lectures, questions and answers, and exercises (expository); (2) Exploration, Elaboration and Confirmation (EEC) Learning measures do not depict to the existence of active learning. In addition, there was no stage of exploration on learning activities; (3) Unoperational and detailed learning measures; (4) No media learning other than the package book; (5) Student Worksheets (SW) used are not teaching materials as guides for learning activities but rather a form of practice questions; and (6) teaching materials on the package book does not present understanding of students mathematical concepts but is more likely to direct them to the steps (procedural) computing.

Furthermore, a test for students to explore the extent to which the learning obstacle faced them on the material changed the fractional shape to the decimal form and vice versa, as well as comparing the fraction and implementation of decimal fraction concept. Diagnostic test results show that students have a learning obstacle in the ability to conceptualize the material basic concept of decimal fraction shown in table 1. 
Table 1. Percentage of student errors on diagnostic tests on understanding decimal fractional concepts

\begin{tabular}{clc}
\hline No & \multicolumn{1}{c}{ Understanding Indicators } & Percentage \\
\hline 1 & Redeclare concepts that have been studied & 40.0 \\
2 & Transforming a form of representation into other forms & 40.0 \\
3 & $\begin{array}{l}\text { Presenting concepts in various forms of mathematical } \\
\text { representation (tables, graphs, diagrams, sketches, }\end{array}$ & 92.8 \\
& mathematical models or other ways) & \\
\hline
\end{tabular}

Based on table 1 above, it can be seen that students ' percentage of an error on indicators numbers $1,2,3$, and 4 respectively amounted to $40.0 \%, 40.0,92.8 \%$, and $82.1 \%$. The smallest student error percentage is located in indicators numbers 1 and 2, while the largest student error percentage is located in indicator number $3(92.8 \%)$. The diagnostic test results show that most students are still not able to present the concept of decimal fractional in various forms of mathematical representation. In measuring this ability, students are asked to describe a shape indicating a specific decimal fraction. In addition, most students are also did mistakes in applying the concepts of the decimal fraction logically. To measure this ability students are asked to solve a story related to a decimal fraction.

Based on the results of the diagnostic test, it is determined that the design of didactic to be designed is the didactic by utilizing a storybook related to fractional material. The storybook used consists of two storybooks titled "Menyelamatkan Diri dari Pulau Tengkorak" and "Potong Semakin Kecil dan Semakin Kecil Lagi".

\section{Didactical Design Plan}

The preparation of the design was done through three phases: prospective analysis, metapedadidactic analysis, and re-prospective. These three stages will be outlined as follows.

\section{Prospective analysis}

At this stage, precise design of teaching materials and learning scenarios is determined by utilizing the storybook. In making the effective learning process, students are equipped with Student Activity Sheet (SAS) which contains several questions and instructions that are expected to help students better understand the book and direct students to the achievement of indicators. The chosen learning model is a cooperative learning model with several methods, including observation methods, questions and answers, discussions, and assignments.

In general, in group learning activities, students are asked to understand and discuss the contents of the storybook as a material to fill the SAS. For students to be more active in the discussion process, during the discussion process the teacher conducts the assessment. Decimal fractional material studied in grade 6 of the K-13 curriculum is associated with the 
competency standard: [5] Solving the fractional calculate operations in problem-solving, and the basic competency: [5.2] Converts the fraction to decimal form. While the basic competency indicator is described as follows: [5.2.1] redefines the meaning of a fraction, [5.2.2] explains the meaning of decimal fractions, [5.2.3] explains the place value of a decimal fraction, [5.2.4] changes the usual fraction to the decimal fraction and vice versa, and [5.2.5] compares the decimal fraction.

In achieving the learning indicators and objectives, it is then designed to be a description of the learning activities that include teacher activities, students, and student response predictions accompanied by the anticipation of its didacticism. Learning activities are allocated to 2 meetings. At the first meeting, students are directed to: [5.2.1] redefine the meaning of fractions, and [5.2.2] explain the meaning of decimal fractions. The teaching materials used for the first meeting are the storybooks with the title "Menyelamatkan Diri dari Pulau Tengkorak (Escape from Skull Island)", written by Okim Choi and published by PT. Gramedia Pustaka Utama Jakarta.

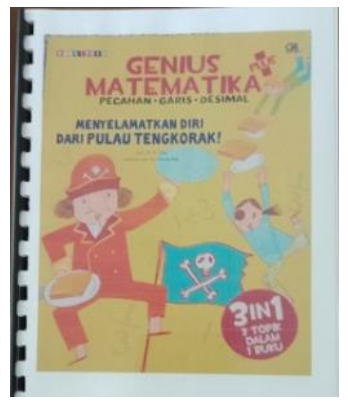

(a)

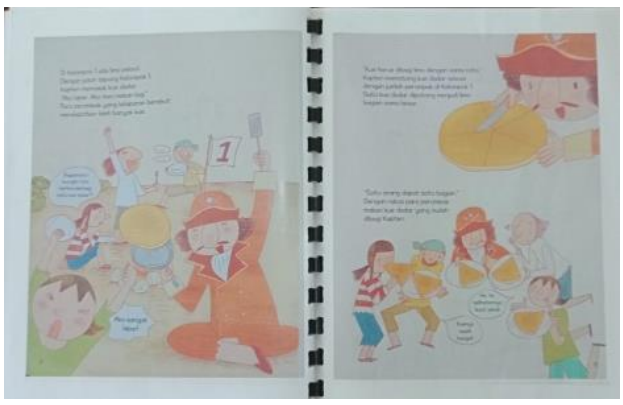

(b)

Figure 1. (a) a book Cover; (b) part of book content

While at the second meeting the students are directed to reach the indicator: [5.2.3] explaining the place value of a decimal fraction, [5.2.4] changed the usual fraction to the decimal fraction and vice versa, and [5.2.5] compares the decimal fraction. The teaching materials used for the second meeting are the storybooks with the title "Potong Semakin Kecil dan Semakin Kecil Lagi (Cut It Smaller and Smaller Again)”, written by Sang-Hyo Gil and published by PT. Gramedia Pustaka Utama Jakarta, 2011.

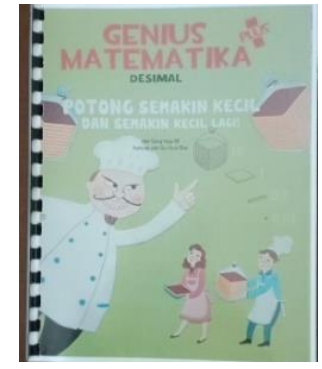

(a)

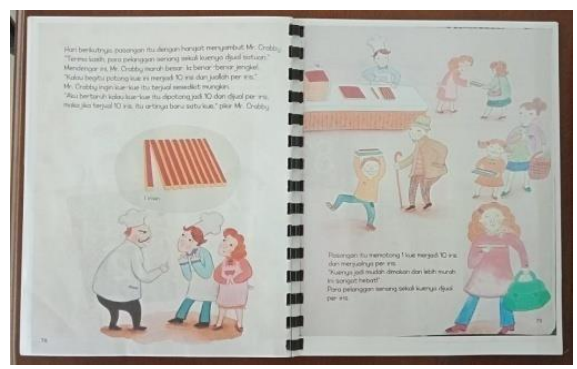

(b)

Figure 2. (a) a book Cover; (b) part of book content 
The design of the first and second meetings has three phases of core activities: exploration, elaboration, and confirmation. The three stages of each meeting will be outlined below.

First learning

Exploration

At this stage, teacher provides several questions to explore the students ' initial ability to share, for example the first question: "There is a mother buying 10 oranges if a family member is 5 people." What should a mother do? How many oranges does each family member have? How is the mathematical sentence of the problem? Second question: "How if there is 1 citrus distributed to 2 people?" How does the mathematical sentence form? Can I find the split difference on the first and second questions?

At this stage, students answer: "Share the orange, each of which gets 2 pieces, 10:5 = 2. As for answering the second question, students answered: "Each got 1/2 the result of the first division of the horns intact and the two horns were not intact." From students' answers, it appears that the split results are two possibilities, i.e. original number or fraction.

\section{Elaboration}

At this stage, teachers do the activities: (1) Ask, who likes to read the story book? Then, inform students that they will learn the divisions that are not intact through the story book; (2) Ask students to read and understand the books shared with each group; (3) Ask students to discuss filling the SAS in groups (Teachers monitor, assess and provide guidance if necessary); and (4) Ask students to present the results of the discussion (teachers guiding the presentation).

While students do the activity answered the teacher question. "I am, I am...," Students then read and understand a storybook with a group of friends ( 3 people), followed by a discussion to answer the SAS, and concluded with the activity of presenting the results of the discussion by their respective groups.

\section{Confirmation}

At this stage, teachers comment on student discussion results (reinforcing correct answers and straightening out erroneous answers) and directing students to make conclusions. Students pay attention to the teacher and make conclusions.

Second learning

Exploration

At this stage, teacher gives a question of digging up the students' initial skills regarding the value of place number, for example: "Mother has 2 bands bound by one hundred 
and one hundred, 4 bands tied by ten and 3 rods which are not bound. What is the right number to symbolize the number of mothers?"

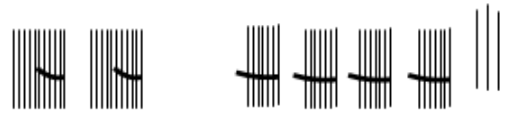

Figure. 3. Lidi Bond

The teacher continues to the question: "Do you remember the value of the place of every number in numbers 243 ? (If the student forgets, the teacher reminds me again). What do you think is called hundreds, dozens, and units? (If students have difficulty answering, the teacher asks students to observe the picture of the bonds of Lidi.) Which is the least value of numbers? According to you, could there be a smaller place value than a unit? (If the student does not answer, the teacher gives the referring question.) Remember the name of the number $32.5 ; 1.23 ; 035$ ? What are the value names of the number of places? Can you describe the value of the place as well as the number 243 shown in the Lidi?

While students are: "Lidi, Lidi..."; 243 (two hundred and forty-three); 2 Hundred, 4 ten and 3 units; Students (perhaps) think and answer because 2 shows many of bonds a hundred, 4 the number of ten-ten and 3-no-group bonds; Unit place value; Students think (maybe students do not answer); Students replied: The "decimal number" (probably) student is confused by the name of the place of the number behind the comma. From this activity, it is hoped that students want to know about the value where the numbers are behind a comma on decimal numbers and are expected to emerge a spirit of reading the storybook. Therefore, Guru continues, "well... To get this answer let, we together read the storybook! "

\section{Elaboration}

At this stage, teachers: ask students to read and understand the books shared with each group (teachers judge); Retelling the core of the storybook and explaining the instruction in the Student Activity Sheet (SAS); Have students discuss completing the SAS in groups (Teachers monitor, assess and member guidance if necessary); and have students present the results of the discussion (teacher guides and assesses the presentation). At this stage, students read and understand the storybook with a group of friend, they follow along, and discuss to fill in the SAS, and then they present the results of the discussion through teacher's guidance.

\section{Confirmation}

At this stage, teacher comments on the results of the student's discussion (reinforcing the correct answer and straightening out the wrong answer), informing him that the value of the number place behind a comma is tenth (one digit behind a comma), a hundredth (two digits behind a comma) and so on and directing students to make conclusions. While the 
students follow along, then conclude that the fraction $0.1=1 / 10$ (one part of 10 parts) and $0.01=1 / 100(1$ part of the 100 section $)$.

\section{Metapedadidactic Analysis}

First Learning

The first didactical design for the indicator: [5.2.1] redefines the meaning of fractions, and [5.2.2] explains the meaning of decimal fractions, as a whole has not been done as planned. Some activities that appear outside of planning include: (1) Although students are very enthusiastic at the time the teacher shares the storybook, however, it turns out that students need a very long time to fill in the activity sheet. This is because students only focus on the story, but not focus on the mathematical concept that appears on the story; (2) The provision of Student Activity Sheets (SAS) makes some students less focused on the storybook; (3) The determination of group members consisting of 3 or 4 people is less effective because the discussion process becomes not maximal; (4) At the time of the presentation, students are reluctant to come to the front of the class, this is because students are not accustomed to performing in front of the class. Because of these two things, the training activities, in the end, have not been done in the classroom but brought home to be used as homework.

Based on the above events, researchers have finally made revisions to the didactical design of the second meeting, namely: (1) a group of 3 or 4 people who were converted into 2 persons (working with a bench friend); (2) Students are emphasized that there is a group assessment during the discussion process; (3) The teacher Shares Student Activity Sheet (SAS) after students have finished reading and understanding the content of the storybook; and (4) The teacher first explains the intent of the questions or instructions on the SAS before the student initiates the discussion activity.

Second learning

Revisions made to the didactic design for a second meeting based on the events that arose at the first meeting gave enough meaningful changes to the learning process. Student responses by the predictions are actionable by the teacher by giving anticipated pre-planned anticipation. While students' responses that appear outside of the prediction can be followed up by the teacher by giving the didactic response according to the existing conditions.

\section{Retrospective Analysis}

Based on the observation results, the first didactic design implementation shows that there are still discrepancies between the concept and its implementations. However, the learning process demonstrates different learning nuances with previous learning. Because 
students are actively learning through the provided resources (storybooks) and there are also multi-directional interactions (students, student-teaching materials, and students-teachers). The implementation of the second didactical design shows progress compared to the first meeting. A more conducive and meaningful learning process depicts students more relaxed and enjoying the mathematical learning process. Timing to share Student Activity Sheets (SAS) after students understand the content of the storybook greatly impacts the student's concentration on reading and understanding the mathematical stories and concepts in it. Besides, the process of discussion and exercise is more vivid because the teacher has already prepared a reward for the students. The following is presented a percentage table of the student error after didactic design implementation.

Table 2. Student error percentage after didactic design implementation

\begin{tabular}{clr}
\hline No & \multicolumn{1}{c}{ Understanding Indicators } & Percentage \\
\hline 1 & $\begin{array}{l}\text { Redeclare concepts that have been studied } \\
\text { Presenting concepts in various forms of mathematical representation } \\
\text { (tables, graphs, diagrams, sketches, mathematical models or other }\end{array}$ & 16.7 \\
& $\begin{array}{l}\text { ways) } \\
\text { Redeclare concepts that have been studied }\end{array}$ & 16.7 \\
& $\begin{array}{l}\text { Presenting concepts in various forms of mathematical representations } \\
\text { (tables, graphs, diagrams, sketches, mathematical models) }\end{array}$ & 6.7 \\
3 & $\begin{array}{l}\text { Identify the properties of the operation or concept } \\
\text { Give examples or examples of cons of the concepts learned }\end{array}$ & 23.3 \\
5 & Transforming a form of representation into other forms & 6.7 \\
\hline
\end{tabular}

Based on the above data, it can be seen that the student's fault rate in resolving the problem of fractional conception and decimal fraction becomes smaller. Thus, it can be concluded that the design of learning by utilizing storybooks can help reduce students ' learning barriers. This strengthens the idea of Prawiradilaga (2015) in his book that the learning process occurs because of the conditions of learning. Learning conditions such as the family environment (Putri et al., 2019), Psychosocial (Latifah et al., 2018; Hujaemah, et al., 2019; Busyaeri \& Aslamiyah, 2020), Learning Style (Patimah \& Abdullah, 2018), Learning Media (Latifah \& Isnaini, 2015; Supardi et al., 2015; Juhji, 2017; Susmayati \& Rachmiati, 2019; Juhji \& Nuangchalerm, 2020), model (Martiani, et al., 2016; Arifuddin, 2016; Muafikoh, et al., 2019), and the method (Arifuddin \& Arrosyid, 2017; Herawati et al., 2019; Mutmainah, et al., 2019; Syaepudin \& Juhji, 2020) influenced the learning outcomes of learners.

The use of the decimal fraction concept in Storybook has been implemented in the learning process. It has been following to the theory of mathematical learning in elementary 
school. From the psychological aspect, learning by utilizing the storybook can help bridge the abstract mathematical concept with the students's level of thinking are still in the thinking phase of concrete operations. This is in line with the research of Hamidah et al (2018) that the use of story contexts can help students understand. An interesting story with illustrations and related to the context of real awareness makes students easier to understand and interpret the mathematical concepts learned. Piaget in Anwar, et al (2018) revealed children in the age range of 7-12 years thinking its logic is based on the physical manipulation of objects or events directly experienced by the child.

From the theories of learning, learning is following to the paradigm of constructivism, because the learning process is done by students by self-construction with the help of teaching materials provided. The development theory of Piaget represents constructivism as it sees cognitive development as a process in which the child actively builds the system of meaning and understanding of real threads through their experiences and interactions.

\section{The final form of didactic design by utilizing storybook}

Based on the results of the first and second didactical design development, it can be concluded that the storybook is very likely to be used as a teaching material for learning mathematics at the elementary school level. The steps that teachers need to note are as follows: (1) analyzing the suitability of mathematical concepts covered in storybooks with competency standards, basic competencies and learning indicators; (2) Ensure students have mastered prerequisite material such as reading smoothly; (3) Prepare Student Activity Sheets (SAS) to assist students in achieving understanding of the mathematical concepts listed on the story; (4) Group students into small groups (2-4 people); (5) Ask students to read the story and record the conclusion while reading results; (6) Asking students to discuss activities on the student activity sheet (the tinting is not shared in conjunction with the storybook, but after Stage 5 is performed); (7) Ask students to present the reading results and the Student Activity Sheet (SAS) that have been discussed; (8) Confirm the correct concept and straighten the wrong concept; and (9) give exercises of varying problems to sharpen understanding. The results of this study are in line with the results of Yun-fang's research (2012) which stated that didactic design needs to be reviewed and reviewed with student learning and characteristic teaching principles. In line with that, Lo \& Hew (2017) provide advice on course planning, out-of-class learning, and classroom learning. 


\section{CONCLUSION}

The utilization of Literature-based math (storybook) in mathematical learning of decimal fraction concept is necessary because it can help reduce to the learning barriers experienced by elementary school students in the aspect of understanding decimal fractional concept. In addition, learning by utilizing storybooks can also bring out more interesting, meaningful and multi-directional learning interactions between students-teachers, students and learning resources. The didactical design developed by research was made for two meetings and experienced a one-time revision. The final outcome of the study is a general learning step that can be done by utilizing the storybook as a learning resource. Recommendations from this research can be utilized by students, teachers, or lecturers to implement effective mathematical learning methods and techniques on the concept of decimal fractions by using storybooks as learning resources.

\section{REFERENCES}

Anwar, N., Budiharti, B., Rudyanto, H. E., \& Marsigit, M. (2018). Matematika untuk Sekolah Dasar; Sebuah Pendekatan Realistik Reflektif. Matematika.

Arifuddin, A. (2016). Pembelajaran Matematika Model Quantum Teaching dengan Pendekatan Realistik untuk Meningkatkan Kemampuan Pemahaman Konsep Peserta Didik. Al Ibtida: Jurnal Pendidikan Guru MI, 3(2), 186-196.

Arifuddin, A., \& Arrosyid, S. R. (2017). Pengaruh metode demonstrasi dengan alat peraga jembatan garis bilangan terhadap hasil belajar matematika materi bilangan bulat. $A l$ Ibtida: Jurnal Pendidikan Guru MI, 4(2), 165-178.

Bafile, C. (2001). Math and literature-a match made in the classroom. Education World, 1-3.

Busyaeri, A., \& Aslamiyah, T. (2020). Korelasi antara Kesiapan Belajar dengan Hasil Belajar Mata Pelajaran SKI Kelas III Madrasah Ibtidaiyah. IJEE: Indonesian Journal of Elementary Education, 1(1).

Chang, S. L. (2006). The systematic design of instruction. Educational Technology Research and Development, 54(4), 417-420.

Cragg, L., \& Gilmore, C. (2014). Skills underlying mathematics: The role of executive function in the development of mathematics proficiency. Trends in neuroscience and education, 3(2), 63-68.

Desmet, L., Grégoire, J., \& Mussolin, C. (2010). Developmental changes in the comparison of decimal fractions. Learning and Instruction, 20(6), 521-532.

Dick, W. (2013). A model for the systematic design of instruction. Instructional Design: International Perspectives I: Volume I: Theory, Research, and Models: Volume Ii: Solving Instructional Design Problems, 361. 
Dick, W., Carey, L., \& Carey, J. O. (2001). The systematic design of instruction (5th). New York: Longmann.

Edriati, S., Handayani, S., \& Sari, N. P. (2017). Penggunaan Teka-Teki Silang Sebagai Sebagai Strategi Pengulangan Dalam Meningkatkan Pemahaman Konsep Matematika Siswa Sma Kelas Xi Ips. Jurnal Pelangi, 9(2).

Fazio, L., \& Siegler, R. S. (2011). Teaching fractions (Vol. 22). International Academy of Education.

Febriyanto, B., Haryanti, Y. D., \& Komalasari, O. (2018). Peningkatan pemahaman konsep matematis melalui penggunaan media kantong bergambar pada materi perkalian bilangan di Kelas II Sekolah Dasar. Jurnal Cakrawala Pendas, 4(2), 266424.

Hadi, S., \& Kasum, M. U. (2015). Pemahaman konsep matematika siswa SMP melalui penerapan model pembelajaran kooperatif tipe memeriksa berpasangan (Pair Checks). Edu-Mat: Jurnal Pendidikan Matematika, 3(1).

Hamidah, D., Putri, R. I. I., \& Somakim, S. (2018). Eksplorasi Pemahaman Siswa pada Materi Perbandingan Senilai Menggunakan Konteks Cerita di SMP. Jurnal Riset Pendidikan Dan Inovasi Pembelajaran Matematika (JRPIPM), 1(1), 1-10.

Haury, D. L. (2001). Literature-Based Mathematics in Elementary School. ERIC Digest.

Hendriana, H., Rohaeti, E. E., \& Sumarmo, U. (2017). Hard skills dan soft skills matematik siswa. Refika Aditama.

Herman, T. (2004). Mengajar dan Belajar Matematika dengan Pemahaman. Jurnal Mimbar Pendidikan, XXIII(1), 39.

Herawati, L., Saefurohman, A., \& Juhji, J. (2019). Pengaruh metode eksperimen terhadap pemahaman konsep siswa MI pada materi sifat dan perubahan wujud benda. Primary: Jurnal Keilmuan dan Kependidikan Dasar, 11(01), 69-76.

Hujaemah, E., Saefurrohman, A., \& Juhji, J. (2019). Pengaruh penerapan model snowball throwing terhadap hasil belajar ipa di sekolah dasar. Muallimuna: Jurnal Madrasah Ibtidaiyah, 5(1), 23-32.

Hurst, M. A., \& Cordes, S. (2018). Children's understanding of fraction and decimal symbols and the notation-specific relation to pre-algebra ability. Journal of Experimental Child Psychology, 168, 32-48.

Juhji, J. (2017). Upaya mengatasi miskonsepsi siswa pada materi sistem saraf melalui penggunaan peta konsep. Formatif: Jurnal Ilmiah Pendidikan MIPA, 7(1).

Juhji, J., \& Nuangchalerm, P. (2020). Interaction between science process skills and scientific attitudes of students towards technological pedagogical content knowledge. Journal for the Education of Gifted Young Scientists, 8(1), 1-16.

Lai, M. Y., \& Wong, J. P. (2017). Revisiting decimal misconceptions from a new perspective: The significance of whole number bias in the Chinese culture. The Journal of Mathematical Behavior, 47, 96-108. 
Latifah, L., Alfiani, D. A., \& Andini, A. (2018). Pengaruh Perkembangan Psikososial Terhadap Hasil Belajar PPKn Siswa Kelas IV MIN Kota Cirebon. Al Ibtida: Jurnal Pendidikan Guru MI, 5(2), 249-260.

Latifah, L., \& Isnaini, I. (2015). Pengaruh media gambar visual terhadap hasil belajar siswa pada mata pelajaran bahasa inggris di mi an-nur pekalipan kota cirebon. Al Ibtida: Jurnal Pendidikan Guru MI, 2(1).

Lee, H. S., DeWolf, M., Bassok, M., \& Holyoak, K. J. (2016). Conceptual and procedural distinctions between fractions and decimals: A cross-national comparison. Cognition, $147,57-69$.

Lidinillah, D. A. M., Apriliya, S., Muliyasari, D. N., Andriani, E. N., \& Pratiwi, V. (2015). Buku Bacaan Anak Berbasis Karakter Sebagai Sumber Belajar Matematika di Sekolah Dasar. Prosiding Seminar Nasional Matematika Dan Pendidikan Matematika UMS.

Lo, C. K., \& Hew, K. F. (2017). Using “first principles of instruction” to design secondary school mathematics flipped classroom: The findings of two exploratory studies. Journal of Educational Technology \& Society, 20(1), 222-236.

Luritawaty, I. P. (2018). Pembelajaran take and give dalam upaya mengembangkan kemampuan pemahaman konsep matematis. Mosharafa: Jurnal Pendidikan Matematika, 7(2), 179-188.

Martiani, E., \& Rachmiati, W. (2016). Penerapan Model Problem Posing Untuk Meningkatkan Hasil Belajar Matematika Tentang Operasi Hitung Campuran. Ibtida ' $i$ : Jurnal Kependidikan Dasar, 3(02), 157.

Mattuvarkuzhali, C. (2012). Remedial teaching in mathematics through multisensory strategies. IOSR Journal of Mathematics, 1(5), 1-4.

Mensah, J. K., Okyere, M., \& Kuranchie, A. (2013). Student attitude towards mathematics and performance: Does the teacher attitude matter. Journal of Education and Practice, 4(3), 132-139.

Muafikoh, M., Mustofa, M., Hasbullah, H., \& Juhji, J. (2019, December). The Influence of Reciprocal Learning Model for Student Learning Activities in Madrasah Tsanawiyah Pipitan Walantaka Serang City. In Proceeding 1st Annual International Conference on Islamic Education and Language: The Education and 4.0 Industrial Era in Islamic Perspective (pp. 449-452).

Novitasari, L., \& Leonard, L. (2017). Pengaruh kemampuan pemahaman konsep matematika terhadap hasil belajar matematika. Prosiding Diskusi Panel Nasional Pendidikan Matematika. Fakultas Teknik, Matematika, Dan Ilmu Pengetahuan Alam Universitas Indraprasta PGRI, 758-766.

Palpialy, J. J., \& Nurlaelah, E. (2015). Pengembangan desain didaktis materi pecahan pada Sekolah Menengah Pertama (SMP). Jurnal Matematika Integratif, 6184.

Pamungkas, Y., \& Afriansyah, E. A. (2017). Aptitude Treatment Interaction terhadap Kemampuan Pemahaman Matematis Siswa. Jurnal Pendidikan Matematika RAFA, 3(1), 122-130. 
Patimah, P., \& Abdullah, F. (2018). Pengaruh Penerapan Gaya Belajar Terhadap Kemampuan Membaca Intensif pada Pelajaran Bahasa Indonesia Siswa SD Negeri Sunyaragi 1 Kota Cirebon. Al Ibtida: Jurnal Pendidikan Guru MI, 5(1), 133-144.

Planinic, M., Milin-Sipus, Z., Katic, H., Susac, A., \& Ivanjek, L. (2012). Comparison of student understanding of line graph slope in physics and mathematics. International Journal of Science and Mathematics Education, 10(6), 1393-1414.

Prawiradilaga, D. S. (2015). Prinsip desain pembelajaran. Kencana.

Priyambodo, S. (2016). Peningkatan Kemampuan Pemahaman Konsep Matematis Siswa dengan Metode Pembelajaran Personalized System of Instruction. Mosharafa: Jurnal Pendidikan Matematika, 5(1), 10-17.

Purpura, D. J., Hume, L. E., Sims, D. M., \& Lonigan, C. J. (2011). Early literacy and early numeracy: The value of including early literacy skills in the prediction of numeracy development. Journal of experimental child psychology, 110(4), 647-658.

Purwanti, R. D., Pratiwi, D. D., \& Rinaldi, A. (2016). Pengaruh Pembelajaran Berbatuan Geogebra terhadap Pemahaman Konsep Matematis ditinjau dari Gaya Kognitif. AlJabar: Jurnal Pendidikan Matematika, 7(1), 115-122.

Putri, N. E., Nirwana, H., \& Syahniar, S. (2019). Hubungan kondisi lingkungan keluarga dengan hasil belajar siswa sekolah menengah atas. JPGI (Jurnal Penelitian Guru Indonesia), 3(2), 98-102.

Reys, R., Lindquist, M., Lambdin, D. V., \& Smith, N. L. (2014). Helping children learn mathematics. John Wiley \& Sons.

Sari, E. F. P. (2017). Pengaruh Kemampuan Pemahaman Konsep Matematika Mahasiswa Melalui Metode Pembelajaran Learning Starts With A Question. Mosharafa: Jurnal Pendidikan Matematika, 6(1), 25-34.

Stylianou, D. A. (2011). An examination of middle school students' representation practices in mathematical problem solving through the lens of expert work: Towards an organizing scheme. Educational Studies in Mathematics, 76(3), 265-280.

Supardi, S. U., Leonard, L., Suhendri, H., \& Rismurdiyati, R. (2015). Pengaruh media pembelajaran dan minat belajar terhadap hasil belajar fisika. Formatif: Jurnal Ilmiah Pendidikan MIPA, 2(1).

Suraji, S., Maimunah, M., \& Saragih, S. (2018). Analisis kemampuan pemahaman konsep matematis dan kemampuan pemecahan masalah matematis siswa smp pada materi sistem persamaan linear dua variabel (SPLDV). Suska Journal of Mathematics Education, 4(1), 9-16.

Suryadi, D. (2013). Didactical design research (DDR) to improve the teaching of mathematics. Far East Journal of Mathematical Education, 10(1), 91-107.

Suryadi, D., \& Suratno, T. (2016). Monofgraf Didactical Design Research. Bandung: Rizqi Press. 
Susmayati, S., \& Rachmiati, W. (2019). Pengembangan Media Sirkuit Lingkaran untuk Memudahkan Siswa dalam Memahami Konsep Volume Kubus dan Balok. Primary: Jurnal Keilmuan dan Kependidikan Dasar, 11(01), 1-16.

Syaepudin, S., \& Juhji, J. (2020). The Effect of Using Powerpoint Media on Student Learning Outcomes in the Material Adaptation of Living Things. Pedagogi: Jurnal Penelitian Pendidikan, 7(1).

Warries, E. (1990). Theory and the systematic design of instruction. Research on Instruction: Design and Effects, 1-19.

Wulandari, D. P. (2015). Meningkatkan Pemahaman Konsep Matematika Siswa SD Melalui Pembelajaran Dengan Pendekatan Problem Posing. EduHumanioral Jurnal Pendidikan Dasar Kampus Cibiru, 7(2), 131-139.

Yanti, R., Laswadi, L., Ningsih, F., Putra, A., \& Ulandari, N. (2019). Penerapan pendekatan saintifik berbantuan geogebra dalam upaya meningkatkan pemahaman konsep matematis siswa. AKSIOMA: Jurnal Matematika Dan Pendidikan Matematika, 10(2), 180-194.

Yıldız, C., Taşkın, D., Köğce, D., \& Aydın, M. (2011). The effect of instructional materials developed in relation to decimal fractions on success. Procedia-Social and Behavioral Sciences, 15, 859-863.

Yun-fang, J. I. A. (2012). Application of Systematic Design of Instruction in Methods of Mathematical Physics Teaching in Higher Education. Higher Education Forum, 1, 17. 